\title{
Unleashing the Potential of Collaborative Governance Arrangements: Getting to Robust Durability in the Blackfoot Valley
}

\author{
Edward P. Weber ${ }^{1}$ \\ ${ }^{1}$ School of Public Policy, Oregon State University, Corvallis, Oregon, USA \\ Correspondence: Edward P. Weber, School of Public Policy, 307 Gilkey Hall, Oregon State University, Corvallis, \\ Oregon 97331-6206, USA. E-mail: Edward.Weber@UNLV.EDU
}

Received: March 28, 2012 Accepted: May 8, 2012 Online Published: June 15, 2012

doi:10.5539/jsd.v5n7p35 URL: http://dx.doi.org/10.5539/jsd.v5n7p35

\begin{abstract}
If collaborative governance arrangements are something to be valued and if they can help us to improve our ability to resolve collective action problems, then it behooves scholars to develop a good understanding of the elements associated with institutional durability. This paper focuses on the concept of robust durability because it captures the importance of problem-solving effectiveness as well as institutional durability. The problem, of course, is that the puzzle of durability is a difficult one to unlock given that collaboration is hard to do and robust durability even harder. The award winning, highly successful Blackfoot Challenge case of collaborative watershed management in Montana, however, offers lessons about robust durability across almost two decades. The lessons involve more than just institutional design, appropriate antecedent conditions, and a supportive external environment. Instead there are a series of variables wrapped up in the operational dynamic inside the collaborative that appear to matter most. Robust durability in the case of the Challenge relies on the character of the organization, continuity of leadership, a multi-faceted managerial strategy, and the application of a systematic fiscal strategy.
\end{abstract}

Keywords: collaboration, watershed management, durability, management, stakeholder, governance, natural resources

\section{Introduction}

\subsection{The Problem of Durability}

There is a clear pattern in the vast majority of community-, watershed-, and landscape-based collaboratives focused primarily on natural resource management. Many struggle to even get started and/or manage only nominal problem solving success. After all, it is well established that collaboration is hard to do, whether at the local/community or larger landscape scale. Other efforts get started and do well, yet their problem solving capacity tends to plateau over time, suffer from diminished capacity, or fizzle out altogether as a viable institution within a few years. Thus, another axiom of most collaboratives; it is hard to sustain problem solving effectiveness and viability over time (Amy, 1987; Layzer, 2008; Lubell, 2005).

The minimal success, diminished capacity and institutional demise outcomes associated with collaboratives occur despite the fact that many embrace the appropriate rules, design elements, and norms typically connected with collective decision-making success (Ostrom, 1990; Leach \& Pelkey, 2001). The general lack of durability is also despite the fact that many collaboratives encounter and maintain favorable antecedent conditions such as severe problem settings (Ostrom, 1990), strong social capital (Putnam, 2000), high cultural or belief homogeneity (Sabatier et al., 2005), good scientific information (Sabatier et al., 2005), and/or entrepreneurial leadership (Heikkila \& Gerlak, 2005).

We also know that, to the extent collaboratives can count on a supportive political, administrative (champions in key agencies) (Selznick, 1957), economic (good economy and adequate resources) environment (Beierle \& Cayford, 2002), and other contextual support they are more likely to be successful. But again, while no doubt important, too many cases exist where the external conditions did not change, yet the problem solving capacity of the collaborative declined or even collapsed. 


\subsection{Improved Durability Equals More Problems Resolved}

Despite the clear issues associated with operating collaboratives, many scholars and practitioners have now concluded that collaborative, networked governance arrangements promise more effective policy implementation and/or collective problem resolution for difficult, important, and relentless public problems (Bingham \& O'Leary, 2008; Dietz \& Stern, 2009; Fung \& Wright, 2003; Sirianni, 2009). As well, community-based collaborative governance arrangements are now positively correlated with environmental sustainability and sustainable communities (Koontz et al., 2004; Mazmanian \& Kraft, 2009; Weber, 2003). The necessary implication of this embrace of collaboratives as an important weapon in the battle to create more effective bureaucracies, even if only supplementary to existing, top-down bureaucratic approaches, is that long-term success requires long-term survival of the basic collaborative governance institution. Thus, if collaboratives are something to be valued and if they can help us to improve our ability to resolve collective action problems associated with the sustainable communities puzzle, then it behooves scholars to get after the conundrum of institutional durability.

\subsection{The Gap in Durability Research}

The gap in durability research is not total. There are many cases of durable, viable collaboratives existing over time in small scale, weak or stateless societies (see generally Ostrom's work). But what about in advanced industrial societies with well developed, strong institutions that, for various reasons, may compete with and constrain, or otherwise hamper, the long-term success of collaboratives? Some sociologists have tackled this conundrum, but from the perspective of theory as opposed to the empirical approach taken here. Another sociologist, Carmen Sirianni (2009), while not attacking the durability question head on and while approaching the question from the closely related project of building civic capacity, makes a powerful case that government has a crucial role to play in supporting the formation and success of collaborative, interconnected unions of civic and public stakeholders. Yet Sirianni's level of analysis is external to collaboratives; he does not examine the internal operational dynamics critical to long-term success. We also know quite a bit about constructing and managing successful single-shot dispute resolution efforts (Daniels \& Walker, 2001). Yet these lessons are, by definition, not focused on durability.

\subsection{Exploring Durability in a Case of Collaborative Watershed Management}

To begin answering the question of durability this research focuses on a case of strong, lasting success-the award winning, highly successful Blackfoot Challenge (BC), a collaborative watershed management effort in Montana, USA. The BC not only is still alive and kicking after 18 years despite the fact that the group has never employed a professional facilitator, but displays what we might call robust durability given its significant increase in problem-solving capacity over time. The robust durability concept enlarges the research question from just institutional durability to include actual problem solving capacity and effectiveness. After all, why should anyone care about maintaining an institutional form of any type if it is not accompanied by problem-solving effectiveness?

In the case of the $\mathrm{BC}$, the collaborative not only failed to plateau, diminish in effectiveness, or cease to exist, it actually strengthened its collaborative problem-solving capacity, often dramatically so. What explains robust durability in the Blackfoot? The answer involves more than just institutional design, appropriate antecedent conditions, and a supportive external environment. Instead there are a series of variables wrapped up in the decision-making and operational dynamics inside the collaborative that appear to matter most. Early on the BC purposively sought to "go slow and be pragmatic" as a way to build a foundation grounded in restored trust and an integrative culture capable of fomenting the kind of change in existing social structures that, in this particular case, accepts and focuses on a cooperative, holistic, interconnected, watershed-wide approach to management. Building this foundation of trust and a common mission in the Blackfoot watershed necessitated the adoption of new ideas crucial to changing the social structure, and a strategic, common sense approach to problem solving challenges in the first few years of the collaborative (Weber, 2009; 2011). Yet, once the foundation for collaboration was built, getting to robust durability relied on a series of other key variables--the character of the organization, continuity of leadership, a multi-faceted managerial strategy, and the application of a systematic fiscal strategy.

\subsection{The Blackfoot Challenge and Its Case for Success}

In 1990, Greg Neudecker, a scientist with the U.S. Fish and Wildlife Service (USFWS) with responsibilities for endangered species recovery, came to the Blackfoot Valley in western Montana. Jim Stone, the owner of Rolling Stone Ranch, was a third generation Montanan and rancher seeking to maintain his livelihood and the property bequeathed to him by his father. He had virtually nothing in common with Neudecker other than a mutually 
shared suspicion of one another and frustration with the status quo--the damage being done by the seemingly intractable series of difficult, interconnected, and relentless public problems common to many rural Western landscapes. In fact, each had come to the same conclusion--the environmental and economic sustainability of the 1.5 million acre watershed was being seriously threatened. For Stone, it was all about "his place and the home for future generations of Stones." For Neudecker, it was about finding a way to discharge his ESA responsibilities successfully in hopes of moving up the management ladder inside the USFWS.

The problems noted by Stone and Neudecker were easy to see and trace. They resulted from roughly 150 years of traditional resource use and development by private and public landowners (US Forest Service; Bureau of Land Management; the State of Montana) that had, over time, significantly degraded a wide variety of natural resources and impaired the ability of the broader ecosystem to function in a healthy, sustainable manner. Thus, by the early 1990s, the Blackfoot watershed contained many threatened and endangered species (i.e., Bull trout, grizzly bears, wolves, Canadian lynx, Westslope cutthroat trout) and was encountering severe problems with dewatered streams (insufficient and, in some cases, zero flows for part of the year), water quality, invasive noxious weeds, and other signs of deteriorating ecosystem health.

While traditional use decisions and methods associated with logging and ranching were central to the story of decline in the Blackfoot, the large number of state and federal environmental policy initiatives passed in the 1970s and 1980s, which were typically crafted as top-down, command-and-control, single issue (fragmented) policies, and the litigation that was a common response, failed to stop the degradation. The new laws also contributed to polarization and declining trust among private landowners, government regulators, environmentalists, and other stakeholders. In addition, the scientific databases capable of understanding and monitoring the nature and extent of the relationships between the multiple resource issues in the Blackfoot fit one of four categories. They either did not exist, or, if they did, the databases were woefully incomplete, fragmented and specific to the proprietary needs of the major landowners in the area, or based on incompatible scientific protocols. Moreover, the Blackfoot watershed, as with so many other beautiful, relatively wild locations throughout the American West, was facing development pressures threatening to transform the tranquil, rustic, and unspoiled area into something far different and less desirable, at least from the perspective of Blackfoot watershed residents.

In short, in 1990 Stone and Neudecker faced a scenario in which the sheer complexity of trying to manage across the entire 1.5 million acre landscape was daunting, the condition of natural resource problems was poor and getting worse, the scientific information needed to move forward effectively was lacking, the community fabric was in tatters, with distrust and vindictiveness replacing productive discussion and collective problem solving, and development pressures were relentless and likely to grow (Ash Institute, 2006; Backus, 2006; Weber, 2009).

Working together, these two leaders were instrumental in founding the Blackfoot Challenge (BC) in 1993 as the primary vehicle for pursuing improved collective governance of, and problem resolution in, the Blackfoot watershed. The $\mathrm{BC}$ is a comprehensive collaborative governance arrangement that includes the USFWS, ranchers, environmentalists, timber interests, recreation groups, state and local agency administrators, other federal agency officials, and watershed landowners and citizens. Since 1993, they have successfully worked with more than 160 private and public partners on watershed-based projects. Stakeholders meet at least once monthly, with meetings open to anyone, meet socially at their annual community BBQ, and, in the case of massive projects, such as the Blackfoot Community Forest Project, meet weekly with the community over an extended period of time (153 weekly meetings were held on this project). The $\mathrm{BC}$ also regularly hosts stewardship outreach (workshops), demonstration projects, and watershed/community tours (6 to 8 each year), while an extensive Education and Outreach program involving hundreds of schoolchildren is used to teach citizens the value of a cooperative conservation approach (Ash Institute, 2006). In many years since 2000 they have had more than 2000 citizens participate annually in $\mathrm{BC}$ meetings and projects out of the watershed total of 8000 (BC Benchmarks of Success, 2006).

After all the hard work, what do we find? We find that Stone is still a rancher and Neudecker still a USFWS scientist/regulator are now friends and colleagues. The Blackfoot Challenge, for its part, has received numerous awards, including the prestigious Innovations in American Government award from Harvard University's JFK School (The Ash Institute) in 2006 and a 2003 award from the federal Clean Water Action Plan that recognized their efforts as one of the "nation's best" for the watershed approach to stream restoration (Ash Institute, 2006; Backus, 2006). The BC has also earned the praise of leaders in both Democratic and Republican administrations. In 1999, Bruce Babbitt, Secretary of the Interior for President Clinton, called the Blackfoot fish restoration projects the best working model in the country for recovering listed trout populations. In 2004, Dirk Kempthorne, Secretary of the Interior for President Bush, called the BC efforts a model for how rural watersheds can move 
toward sustainability (Backus, 2006). Further, national environmental leaders have noted the BC's successes, with Robert F. Kennedy, Jr. praising the $\mathrm{BC}$ as "one of the most innovative and successful watershed management efforts in the U.S." (related to the author by Kathleen Kennedy Townsend, 2006).

In short, the general consensus is that the $\mathrm{BC}$ collaborative is successful. In a general summary, the final site report from the Harvard University Innovations competition describes the $\mathrm{BC}$ as an exemplary collaborative effort engaging local communities in public problem solving and is forging strong, productive links between government agencies-both federal and state-and local expertise. It offers an innovative and pioneering cooperative approach to the complex, and typically politically difficult, problem of restoring, managing, and sustaining the 1.5 million acre Blackfoot watershed's biologically rich natural resources, while simultaneously conserving rural lifestyles and livelihoods. If replicated across America's rural, low density watersheds, which are now recognized as being the new frontline in the battle for restoring and maintaining healthy stocks of endangered species (e.g., salmon, steelhead, bull trout, grizzlies, wolves, etc.), forest, rangeland, grassland and riparian health, and biodiversity, more generally, this significant and measurably effective cooperative program may well become a critical, and perhaps the defining, template for how successfully to marry the management of communities with the preservation and enhancement of nature" (Ash Institute Report, 2006).

Yet, what is the story behind the story? What accomplishments merit the awards, national recognition, and claims of collaborative success? Success here is treated as something more than simply getting people to say they trust each other more, a sign of strong social capital as it were (and it has accomplished that outcome too; see Ash Report 2006, 2). Instead it is argued here that the claim of durability across time needs to be grounded in the kinds of measurable empirical outcomes customarily used to measure effective governance arrangements. More specifically, what is the record of the $\mathrm{BC}$ when it comes to programmatic and organizational/institutional outcomes in the areas of budgets and resources, as well as programs?

\subsubsection{Budgets and Fundraising}

Budget and fundraising successes are often a proxy for programmatic success, or lack thereof, especially when it comes to civic institutions which have no legislatively mandated, permanent operating budgets. Stakeholders have to sell their program and their successes continually. Marketing/sales, however, are unlikely to sustain budget and fundraising success over the long-term in voluntary civic organizations. Far more likely is that many different sources of funding are only willing to commit considerable amounts of money to something like the Blackfoot Challenge's cooperative conservation efforts if and when they can tout an established and verifiable record of programmatic success. On this count there is clear evidence that collaborative efforts in the Blackfoot watershed are enjoying durable success.

Annual budgets for the BC started and stayed at the $\$ 40,000$ to $\$ 60,000$ level throughout the 1990 s into the year 2000 . The annual budgets started to rise significantly in 2001 , more than doubling to over $\$ 100,000$, and then increasing exponentially, with budgets reaching more than $\$ 600,000$ per year in both 2003 and 2004. The remarkable and dramatic budget increases continued into 2005 and 2006, reaching more than $\$ 2,000,000$ in both years, before settling back to $\$ 996,000$ in calendar year 2007, $\$ 924,000$ in 2008, and 1,973,000 in 2009. Most of the new revenue came from government program funds and grants, primarily federal, yet increases in private foundation fundraising have also been significant, exceeding $\$ 750,000$ each year in three years since 2000 , with the top year being $2005(\$ 1.39 \mathrm{M})$, with the average annual foundation contributions from 2006 through 2009 being approximately $\$ 116,000$. Fundraising from individuals also has risen exponentially since 2000, going from an average of between $\$ 3,000$ to $\$ 10,000$ per year to an average of almost $\$ 123,000$ per year for the five years from 2005 through 2009 (Blackfoot Challenge Annual Reports, 2010).

\subsubsection{The Programmatic Record}

Over time the Blackfoot Challenge has established and managed over 100 programs and projects, producing a sizable track record of outcomes benefitting the ecology and human communities of the watershed. The following $\mathrm{BC}$ programs and outcomes are indicative of the kind and range of work that has earned the collaborative national recognition and a series of national performance awards.

Comprehensive Conservation Easements. Starting in 1995, the BC and one of its primary partners, the USFWS, has secured conservation easement coverage on 90,000 acres involving 65 private landowners and 75 easements. This is $30 \%$ of all private property in the watershed (the remaining acreage is owned by Plum Creek Timber). Fully 43,000 acres are covered by USFWS easements and 47,000 acres of easements are coordinated through the Blackfoot Challenge. As with the budgeting story, a significant majority of these easements-60,000 acres-came after 2000. Moreover, both sets of easements employ the innovative comprehensive approach co-developed in 1995 by the BC and USFWS that addresses all parts of a landscape as well as development pressures (Ash 
Institute Report, 2006).

One significant esthetics result is that one will never see a building, home or otherwise, along an 18 mile stretch of the Blackfoot River. The broad coverage also means that considerable steps have been taken toward the dual goals of maintaining the rural character of the landscape and of providing long-term natural resource protection in perpetuity. In this way, according to a biologist, "the more comprehensive easements keep people on the land, while protecting all the critical biological elements" (Personal interview, 2006). In addition, BC stakeholders credit the easements with providing a crucial vehicle for "building trust between the Challenge and landowners because owners see that we value them and their livelihood. This new trust often opens the door to additional environmental restoration and water conservation projects on the property" (Personal interview, 2006).

Water Conservation and Drought Management. Water rights are perhaps the most sacred property right in the American West and are typically not a matter for negotiation, much less sharing with others. The lack of sharing arises from a physical reality as much as anything-most western rivers are over-allocated, and there is no water to share except in high water years. The Blackfoot watershed is no exception to this rule. It also suffers from both periodical and chronic human-related dewatering along 165 miles of streams (out of 3,700 miles total). Yet, the cooperative conservation approach employed by the Blackfoot Challenge has succeeded in alleviating such problems through a four-part approach.

First, in drought years over 70 Blackfoot River irrigators and water users have agreed to share the pain of low water flows by voluntarily donating a minimum of 60 cubic feet per second (cfs) to Blackfoot River instream flows. Science shows that the $60 \mathrm{cfs}$ level is necessary in order to keep water temperatures cold enough to support healthy trout populations and other key biota dependent on the river. Under the "Shared Sacrifice" program rights holders do not lose their rights for lack of use because the contribution is considered a beneficial use under state water law. To facilitate decision-making, the BC installed 15 in-ground soil moisture monitors to assist water rights holders in better managing their required water flows for crops and livestock. The result has been that in every year but one since the program started in 2003, the Blackfoot River has met or exceeded the 60 cfs minimum.

Shared Sacrifice is complemented by other BC policies and programs. There is a fishing ban during periods of high temperature and low water. Fishing bans reduce the biological stress encountered by fish and other aquatic animals during such times. Dozens of ranchers have adopted off-stream stock watering, in which piping systems transport water to watering troughs for livestock located away from stream banks. This minimizes the destruction of stream banks by cattle, thereby minimizing destructive sediment loads, minimizing stream widening and "shallowing" (which unnaturally slows the flow, increases the water temperature, etc.), and allowing riparian vegetation to take hold and provide shade to streams (helps keep the coldwater resource cold). Finally, the $\mathrm{BC}$ has worked to move more than 15 ranchers and farmers out of traditional and highly inefficient gravity flow, flood irrigation systems into piped, center pivot systems that typically take half as much water.

Riparian Habitat, Streams and Water Quality Restoration. Riparian habitat, streams and water quality restoration are critical to endangered and threatened species (Westslope cutthroat trout, bull trout) listed in the 1990s as well as to other flora and fauna critical to the overall ecological health of the Blackfoot watershed. Moreover, by 1996, habitat destruction, excess sediment-loading, and metals contamination led the Montana Dept. of Environmental Quality (MDEQ) to list 56 streams in the watershed as impaired. Impaired means they do not fully support beneficial uses such as aquatic habitat, recreation and drinking water.

In response, the $\mathrm{BC}$ has engaged 147 landowners and 500 projects in areas of the highest ecological value since the mid-1990s. At the leading edge of BC efforts are a series of stream and riparian restoration projects, each of which requires heavy construction equipment and oftentimes major reshaping and displacement of existing terrain. Such projects also require unfettered access to critical stream habitat on private lands. Despite these challenges, results include the restoration of 38 miles of streams (in-stream work to restore flows to natural channels) on 41 different tributaries and 62 miles of riparian areas out of a total possible 1,900 miles of perennial streams capable of supporting fisheries. More than 460 miles of fish passage barriers have been removed, thirteen fish screens designed to prevent fish from getting into irrigation canals have been installed, and 2,600 acres of wetlands have been fully restored. As well, five Water Quality Restoration Plans (TMDL Plans) have been approved by the U.S. Environmental Protection Agency. To track progress, the BC completed a $\$ 150,000$ in 2002 on a suite of physical, chemical and biological items on 12 streams. All but one of the sites showed good biological integrity, minor to no impairment, and full support of aquatic life and other beneficial uses. Nine restored streams have now been removed from the MDEQ list. This effort was followed up in 2004 with a watershed-wide Status and Trends Monitoring Project in which 30 expert volunteer field crews visited 50 
previously "impaired" sites on 25 streams collecting information on stream condition and identifying restoration opportunities. Just as importantly, cutthroat trout populations have benefitted, experiencing a 10-fold increase from 1989 to 2004, while the primary method for counting bull trout populations-the number of spawning redds-has seen an explosion on two of three key streams, rising from 10 or fewer redds in 1989 to an average of over 50 redds in both cases over the ensuing 14 year period.

The Blackfoot Community Forest Project. This is a comprehensive and pioneering effort to restore the ecological and biological integrity of 88,000 acres of Blackfoot land by purchasing private land from Plum Creek Timber and other private landowners, deeding it over to the US Forest Service (Lolo National Forest) in perpetuity, and creating a large common public, or community, area that is jointly owned and managed by community stakeholders. The jointly produced management plan adheres to the $\mathrm{BC}$ mission and was developed using 163 community-wide meetings that were dedicated to this topic over a two year period. The Nature Conservancy, an environmental group, has been active in Blackfoot Challenge activities for over ten years and played the role of interim owner, or "banker" in the multi-million dollar purchase of the 43,000 acres of private land from Plum Creek Timber Co. The control and rationalization of land ownership is designed to protect key parcels of land from future development, promote and protect water quality, provide intact wildlife migration corridors for endangered and other species, and manage the timber using an ecosystem-based approach to forestry.

Endangered Species (other than fish) and Wildlife Conservation. The restored ecological health of wetlands and other riparian areas, the many conservation easements, and the rationalization of land ownership by the Blackfoot Community Project to the benefit of wildlife migration corridors have coupled with the BC's other programmatic efforts to assist with other endangered species and wildlife.

- Human-grizzly bear conflicts have been reduced by $67 \%$ in since 2001 despite significant increases in bear sightings and anecdotal evidence over the last 10 years that grizzlies, listed as threatened under the ESA, are re-colonizing many parts of the Blackfoot area. Programs contributing to these results-more bears, yet fewer conflicts-include abatement measures such as the building of 14,000 linear feet of electrified predator-friendly fencing $(60 \%$ of rancher's calving yards are now fenced), the installation of 80 bear-resistant dumpsters, and a carcass pickup program that removes dead animals (wild game, livestock, road kill) from private property and roads.

- $\quad$ Elk populations, a traditional, key member of the area's ecosystem, are steadily increasing at the rate of $5 \%$ per annum (Blackfoot Watershed, State of the Basin Report 2005, 10).

- Trumpeter swans are native to the area, but have been declining for decades. A trumpeter swan reintroduction program started in 2005 and released 10 birds in the hopes that they will migrate, then return and colonize the Blackfoot area. Dozens more have been released in June of each year since.

- Populations of Canadian lynx, listed as endangered under the ESA, while declining in most areas of the U.S. West, appear to be stable according to John Squires, a USFS wildlife research biologist who has monitored and researched 80 lynx in the area since 1998.

Getting after Noxious Weeds. Many areas of the American West have been overrun by noxious, non-native weeds in the past several decades. These weeds pose a large and growing threat to native vegetation, overall ecological health, and to rural economies (farms and ranches). The cooperative conservation program has been proactive on this front and has engaged 380 landowners, utilizing integrated weed management practices on over 45,000 acres of noxious weeds in 11 different management zones.

\section{Method and Research Design}

The research draws primarily on data from 32 extensive, semi-structured, open ended interviews conducted in May 2006 and July 2008 with key stakeholders involved in the Blackfoot Challenge. Interviewees included stakeholders from environmental groups (Nature Conservancy, Trout Unlimited), large and small logging operations (Plum Creek Timber, Pyramid Lumber), state agencies (Montana Dept. of Natural Resources, Montana Fish, Wildlife and Parks), federal agencies (U.S. Fish and Wildlife Service, U.S. Forest Service, US Natural Resource and Conservation Service), local businesses (Blackfoot Telephone Company, local guest/dude ranches, contractors), ranchers, unaffiliated citizens, and staff of the BC. At least one, and in most cases two or three representatives from each of the stakeholder groups were interviewed. Other data was derived from primary $\mathrm{BC}$ and governmental documents and research reports focused on $\mathrm{BC}$ programs.

The BC was selected because its existence since 1993 meant that it was a "successful" case of durability and thus a good fit for the main research question. At the same time, the broad recognition of success as a collaborative watershed management effort meant that it was not simply a collaborative in name only, rather it had numerous 
important programmatic achievements to its credit. This last part provided a good, and necessary fit to the robust part of the robust durability puzzle since it demonstrated active, successful collaborative problem solving across time.

The case study approach follows the advice of King, Keohane, and Verba (1994) and accepts that rich, descriptive "case studies ... are ... fundamental to social science. It is pointless to seek to explain what we have not described with a reasonable degree of precision" (44). In short, while the data provided by the Blackfoot Challenge case does not provide definitive answers to the main research questions, they are a necessary first step for future research designed to build the kind of explanatory theory that will help us to know with greater certainty which variables matter when it comes to robust durability for collaborative governance arrangements.

\section{Moving Beyond the Foundation to Establish Robust Durability}

Given the diverse backgrounds, interests, and prior battles within the Blackfoot watershed community, the relationships among the stakeholders during the initial years of the Blackfoot Challenge were defined by a high degree of mistrust and little belief that they shared much in common. During this time of high risk for the nascent relationships, the leaders and stakeholders fully recognized that the initial challenge was to rebuild the frayed relationships and establish enough trust to get people talking to each other and sharing the kinds of information necessary for managing and hopefully resolving, or minimizing, the many public problems facing the watershed community. As a key stakeholder explained, "It's an organic process. We had to learn to hold hands and go slow and build a reservoir of trust and credibility" (Personal Interview, 2006).

Yet, while constructing and maintaining the integrative culture, or foundation for collective problem solving is necessary, many collaboratives have surmounted this hurdle without successfully maintaining robust durability for the long term. In this sense, the foundation is not sufficient for the task of ensuring robust durability over the long-term and thus is unable, by itself, to explain how the Challenge was able to survive and thrive over the years. Understanding the rest of the robust durability puzzle requires that attention be paid to several other variables that helped to expand and maintain the BC's overall problem solving capacity, while also attracting and retaining the continuing support of key community members and stakeholders. These variables include the character of the $\mathrm{BC}$ and its member stakeholders, the continuity of leadership, the embrace of a multi-faceted managerial strategy, and the application of a systematic fiscal strategy.

\subsection{The Character of the Organization and Its People}

People are attracted to the people and the Blackfoot Challenge because of its character as much as its ongoing successes. Others want to get involved and help (Personal Interview, 2006).

Interviews made clear that the overall character of the Blackfoot Challenge was a magnet that drew stakeholders to the group. Part of this stemmed from the cooperative conservation ethic. For example, "I joined in 1999 because of the strong cooperative conservation ethic. A lot of people wanted to save the river and watershed. It was an opportunity to work with people who were very forward thinking and had a clear vision about saving their place as a community for a broad range of people and interests" (Personal Interview, 2006). Others liked the fact that "It's not about fighting or advocacy, it's about consensus" (Personal Interview, 2006). Yet these two items are at play in any watershed collaborative embracing such a mission and the rule of consensus. Thus, while important, the cooperative conservation mission and consensus are not enough when thinking about durability. Instead, understanding the attractive character of the $\mathrm{BC}$ requires elements distinctive to the collaborative. There are several.

- A "lead from behind, no one is in front, team first" philosophy attracts "the right kind of person who is better suited to working together for others benefit, can bury their ego, and not worry about whether their name is the one in lights. This helps facilitate our problem solving because we focus on the facts and results, and who can help, not on who gets the credit" (Personal Interview, 2008).

- It is "loaded with good people and community leaders who act as a magnet for others. They are highly intelligent, passionate, it's their home, their life and they enjoy it the BC work" (Personal Interview, 2008).

- There is purposive non-partisanship designed to develop and maintain a reputation as a credible forum for resolving disputes and solving problems. The $\mathrm{BC}$ "bends over backwards to avoid pro-green and pro-development labels" (Personal Interview, 2008).

- The BC is perceived as "a secure organization where participants have a high sense of self-worth in their own lives and what they are doing for the watershed" (Personal Interview, 2008). 
- The "BC is a serious organization that never forgets to have fun. That's why we meet at Trixie's a local pub to unwind and why we have community barbecues. I think it's the most sexy, desirable, fun organization I've ever been affiliated with" (Personal Interview, 2008).

\subsection{Continuity of Leadership}

The Blackfoot Challenge has had the same two primary leaders-Jim Stone (rancher) and Greg Neudecker (USFWS)-since its inception. Others key to the founding have also continued to play key leadership roles. For example, Hank Goetz, long-time director of state-controlled experimental forests for the University of Montana, "has long been a stalwart, passionate advocate of the Blackfoot Challenge's cause. His fingerprints are found on many of the successful projects over the years. He's not afraid to get his hands dirty" (Personal Interview, 2008). Goetz also has been central to the 88,000 acre Blackfoot Community Forest project. Nancy Anderson of the Bureau of Land Management has been on the BC Board since 1998, while Land Lindbergh and Dave Cochran, local landowners and founding members, have served on the board from the beginning.

\subsection{The Managerial Strategy}

The Challenge employs a multi-faceted managerial strategy that envisions itself as hands-on catalyst for directing and ensuring that the work of watershed restoration gets completed in accordance with the cooperative conservation mission. The components of the strategy include:

- the presence of the BC's hands-on board of directors

- the recruitment of "focal" people

- the long-term perspective provided by the mission in combination with a selective partnering approach

- the embrace of staffing changes to fit the different stages of BC growth

- a core catalyst model of minimalist bureaucracy

- $\quad$ and a commitment to transparency and accountability to others

First, many of the stakeholders point to the importance of the BC's pragmatic, hands-on board of directors who are "the heart and soul of the BC, they live it every day. They buy into and practice the mission, the ideas, leadership philosophy and do not turn everything over to staff, which is more typical" (Personal Interview, 2008). Moreover, stakeholders describe Board members as "fully rooted. They live on the land, rely on the land, manage the land whether because they own it or, as government employees, they have a responsibility for it. They do not see their place as an intellectual position; instead they live and breathe the land. They love the place" (Personal Interview, 2008). In addition, BC Board members are leaders in their own right. "Members have their own clear, strong track records of success in various fields and are willing to apply them on behalf of the larger watershed community" (Personal Interview, 2006). Moreover, the hands-on style of the Board "is critical come transition time. If a collaborative is too dependent on staff for direction and programmatic success, then it is problematic for the Board to insert themselves assertively as needed when it is time to change, or to adopt a new way forward in terms of staffing needs" (Personal Interview, 2008).

Second, the Challenge decided within the first few years of their existence to strategically recruit, and add to the BC membership rolls, "focal" people (influencers). Taking a page from the Endangered Species Act (ESA), where focal species critical to maintaining overall ecosystem health get the most attention, the concept is about identifying, recruiting and retaining the leaders, elders and others from across the spectrum that matter most to the social ecology of the watershed. These are the "respected opinion and community leaders," some without official or formal organizational leadership portfolios, as well as agency officials, who "know their communities inside and out" (Personal Interview, 2008).

They have the wisdom, knowledge, integrity and respect of others in the community. They are already credible and trustworthy and others tend to listen (Personal Interview, 2008).

Third, the BC managerial strategy embraces a clear mission that is holistic, comprehensive and focused on "taking care of the valley watershed for the long-term" (Personal Interview, 2008). The mission is comprised of a substantive commitment to cooperative conservation. Cooperative conservation for the BC means maintaining and enhancing "environment, economy and community such that no one piece is favored over another. They all must be healthy if this is going to work" (Personal Interview, 2006). The mission is coupled with a strong commitment to "doing good things" for the community. "If you keep on doing good things-and we have-and take on projects that are near and dear to the hearts of Blackfoot community members, it is easier to keep going" (Personal Interview, 2008). 
To help facilitate and enforce the long-term perspective of the mission the $\mathrm{BC}$ chooses its partners carefully. The Challenge has successfully partnered with over 160 organizations and agencies, yet "the BC does not partner with just anyone and does not like getting involved mid-stream in other group's projects. Partners must have the watershed community's interests at heart; they must be focused on the broader public interest as defined by the BC mission" (Personal Interview, 2008). This is why the BC has been "willing to refuse funding or program ideas if it means compromising our mission. We'd rather stay true to our core principles, the things that we worked out together, than risk it all for a few more dollars" (Personal Interviews, 2006; 2008).

Fourth, the Challenge accepts that organizational needs change over time and that this "is a natural part of growth. We are not afraid to change "staff" horses in the middle of the stream" (Personal Interview, 2008). As a result, multiple leaders have filled the BC's Executive Director position, yet each has possessed a distinctive set of skills and strengths that "fit" the different needs of the BC as it grew from nothing into an accomplished, durable problem-solving collaborative. The original Executive Director was a local psychologist who volunteered to get things started, who was well known throughout the watershed, and who had a trustworthy reputation. His expertise in building trust and "reputation for fair dealing" were good fits during a time when the primary tasks were mission development and building positive, trust-based relationships among a diverse group of stakeholders.

Phase II of the BC's organizational life moved toward collecting scientific information on watershed conditions, and designing and implementing a small handful of programs to improve those conditions. The Board realized that given their overarching focus on water quality and stream restoration as "first" projects-two areas that promised good ecological returns on investments-required a good program manager with considerable technical expertise (Personal Interviews, 2008). They also decided that a successful Executive Director, and the BC, would necessarily benefit to the extent that such a leader already had an established network of state and federal contacts, and a successful record working with government agencies in the water resource and stream restoration arenas.

Phase III began in 2000 and involved a transition to an experienced professional manager. The BC "did not look for just a fundraiser, rather their profile was a successful manager of public organizations or non-profits with clear experience growing and developing organizations, strong on program implementation, but also with no big ego, a record as a team player, and experienced at dealing with failure" (Personal Interview, 2008). Specific fundraising experience with "foundations" and government grants was also a position requirement in Phase III, as was "the right personality." As a result, the BC Board constructed personality profiles of candidates using the Meyers-Briggs test. The new Executive Director fitting these needs was Tina Bernd-Cohen, a former official from the Florida Department of the Environment under Carol Browner (eventually President Clinton's EPA Administrator and President Obama's White House Czar for environmental protection), and a leader of environmentally focused non-profits in the state of Rhode Island.

In 2007, with Bernd-Cohen voluntarily stepping aside, the BC opted to bring on board an Executive Director, Gary Barnett. Feeling comfortable with having established a strong record of programmatic fundraising in the foundation and government worlds, the $\mathrm{BC}$ hired a Director with a proven record raising funds from individuals (see "three-legged stool" fiscal strategy below), along with clear success in program design and implementation.

Fifth, there is the partnering, or what might be called the "core catalyst" model of bureaucratic decision-making, resources and administration. Central decisions are managed by the Blackfoot Challenge-the core-in keeping with its cooperative conservation mission. Yet considerable effort is devoted to catalyzing the resources of others, as well as delegating significant taskings, many times for entire projects, to trustworthy partners. The design targets most of the available resources to on-the-ground problem solving initiatives, not internal BC operations. "We want to keep the central staff small. That's why we work hard to catalyze partners so they can work through program details and implement the programs. After all, they're the ones with the expertise, they're the ones with the experience getting things done, rather than pushing paper" (Personal Interview, 2008). The commitment to the core catalyst minimalist model of administration shows up in the BC's expenditure patterns, which expends an average of over $89 \%$ of total budget dollars on programs in the years 2007 through 2009 (the practice of reporting program versus administrative expenditures started in 2007). This approach to decision-making, resources and administration is a natural outgrowth of two other themes undergirding the BC's management style:

- The "lead from behind, no one is in front, team first approach gives lots of credit to lots of people. This makes it easier for us to attract good partners, whether public or private. They know they'll get credit for their accomplishments. We give them visibility and credibility. We also provide moral support for government 
agencies that are too used to being vilified and hated around the West. Think about it, in most places in Montana and other western states the sentiment is for federal agencies like the Forest Service to own less land, but not here in the Blackfoot, we have invited the Forest Service to buy up more land and work with us to manage it in the 88,000 acre Blackfoot Community Forest project (Personal Interview, 2008).

- The belief that "people make conservation happen" emphasizes the individual responsibility that attaches to citizens of the Blackfoot, as opposed to relying solely on government agencies or others to achieve their mission (Personal Interview, 2008). It also means that getting others to engage and commit to action on behalf of cooperative conservation is seen as crucial for building the kind of collective problem solving, or social capital, that can increase the likelihood of long-term success (Putnam, 2000). "If we can do this, then we have a better chance of working well together even after the money is gone" (Personal Interview, 2008).

The exchange of resources and expertise is a two way street, however, as a key stakeholder from the recreational community attests: "TU Trout Unlimited started coming to BC meetings in the late 1990s in order to find out what this crazy group was doing very distrustful. Now we come because we receive tremendous help and fresh thinking that help us solve conservation and fish problems" (Personal Interview, 2008).

Sixth, and finally, the BC managerial strategy is committed to being accountable to others. The credo of "always measure and monitor, and always be transparent" is viewed by stakeholders as a way "to establish the bona fides of the organization to others", while also placing pressure on themselves to establish a successful track record (Personal Interview, 2008). The documentation and communication of $\mathrm{BC}$ success using valid and understandable indicators fits together with the overall funding strategy: "If we don't do this, why should others fund us or keep funding us?" (Personal Interview, 2006).

\subsection{Systematic Fiscal Strategy}

Understanding the puzzle of robust durability requires that due attention also be paid to the Blackfoot's Challenge's systematic fiscal strategy, grounded as it is in conservatism and a series of elements that complement, and arguably cannot be separated from, the rest of the managerial strategy. The key pieces are several. The BC adopted an initial limited fiscal strategy grounded in four core beliefs, the first of which is that "you don't have to have tons of money to be successful in the early stages because the early keys to success are building relationships and trust" (Personal Interview, 2008). The BC also focused on basic principles of fiscal conservatism "Don't spend what you don't have," and "grow slowly in an affordable, sustainable, controlled fashion" (Personal Interviews, 2008). Further, much like the overall "foundation" concept articulated above, they embraced the idea that they should "target what money they did have" only on low risk, "doable or achievable projects." By establishing a record of success on simpler, easier problems, stakeholders purposely built capacity, thus enabling them to eventually, when the time was ripe and more money available, to tackle more complicated, larger projects which, by definition, become more achievable as problem-solving capacity expands. Taken together, the initial limited fiscal strategy minimized the managerial and staffing dilemmas and distractions that typically accompany rapid growth coupled with an approach that tries to tackle major, complex problems from the start. This then made it easier for stakeholders to stay focused on the early primary tasks of restoring trust, building working relationships, and collecting information.

The BC's systematic fiscal strategy also embraced the belief that long-term success requires the successful creation and maintenance of a diverse, resilient "three-legged stool" funding model. The focus on maintaining the health of, and access to all three legs-individual contributions, government grants, and private foundation money-was designed to avoid organizational brittleness that can stem from an overreliance on one source of funding. It also avoids over-reliance on any one stream of revenue, thus helping the $\mathrm{BC}$ to maintain its independence from any outside funders making demands not in synch with the overall cooperative conservation mission. It means that when one source of funding declines the $\mathrm{BC}$ has improved capacity to exploit the remaining "stools," or revenue streams. For example, in 2003 and 2004, federal agencies such as BLM, USFS, and the USFWS, among others, awarded millions of dollars to collaborative watershed groups. Yet, "many of those that relied primarily or almost wholly on this money failed within a few years. We on the other hand, tapped the federal money and kept right on going after other sources of money and kept on building our partnerships. As a result, our budget is now as of 2008 more than double what it was back then despite the disappearance of government grant money for groups like ours" (Personal Interview, 2008).

An additional piece of the fiscal strategy for the BC involves the use of a "club" model for all partners. Non-profit organizations quite commonly require Executive Board members to commit to either contributing or raising a particular sum of money every year as the price of admission. It helps to give them a tangible stake in the organization or "club." The BC extends this strategy to all partners, over 160 to date, and requires an annual 
minimum of "give or get" at the $\$ 5000$ level.

Further, the Challenge takes a conservative, patient approach to the projects and programs they do fund. The basic rule is "don't do it unless all the funding in place" (Personal Interview, 2008). Such an approach lengthens the calendar and slows progress, while simultaneously reducing the risk of incompletion and failure, this helping the $\mathrm{BC}$ to bolster their reputation for getting things done and getting them done successfully.

The final piece of the BC's systematic fiscal strategy focuses on building financial security for the long-term. Starting in 2006, the Board set a goal of raising a $\$ 3 \mathrm{M}$ endowment in order to create "opportunity money that allows the BC to jump on good ideas as they arise, rather than worrying about raising new funds" (Personal Interview, 2008). By the beginning of 2010 they were more than two-thirds of the way to their goal.

\section{Discussion}

The puzzle of durability for collaborative governance arrangements such as the Blackfoot Challenge becomes ever more important to the extent that scholars, practitioners and policymakers adopt more collaboratives (Bingham \& O'Leary, 2008). At the same time, the question of institutional durability cannot, and should not be detached from the equally important concept of problem-solving capacity since that is a primary reason for adopting collaboratives in the first place. In fact, it is useful to recall that the road to robust durability in Montana's Blackfoot watershed came after the top-down, fragmented policy approaches had been tried for decades and found wanting in the attempt to stop ecological degradation across the 1.5 million acre watershed. As such, the case outlined here offers us a window of opportunity for eliciting variables key to the robust durability puzzle, particularly with respect to its internal operational dynamics. These include the character of the effort and its member stakeholders, the continuity of leadership, the embrace of a multi-faceted managerial strategy, and a systematic fiscal strategy. The case also evidences a strong pattern of programmatic, problem-solving success that clearly and consistently promotes environmental sustainability and the idea of a sustainable community.

Within the academic realm, the limitations of the single case study design means that more work is needed to test and refine the model presented here. Moving this research agenda forward can be as simple as research designs focused on multiple case studies arrayed across a range of cases from high success to failure per Yin (2009), or perhaps the application of the QCA model to a larger set of cases (Ragin, 2008). Such research can also prove instrumental in helping us design frameworks to guide stakeholders in communities seeking to establish long-term, successful collaboratives, whether it is for identifying and training the right type of leader who can work successfully within the "lead from behind, team first" philosophy, or more fully fleshing out key concepts such as focal people, selective partnering, and "hands on" board of directors. Skeptics and curmudgeons, of course, might dispute the need for ever more "how to do collaboration" frameworks, claiming that the market is already saturated. Yet the general lack of successful collaborative governance arrangements fitting the robust durability outcome suggests the opposite-new, more robust models to guide collaborative decision makers are clearly needed (Bingham \& O'Leary, 2008). The need is even more acute when placed in the context of the ongoing push by many to craft and implement new collaborative governance arrangements at all levels of society.

\section{Acknowledgements}

The author would like to thank the professors and graduate students from the University of Indiana's School of Public and Environmental Affairs, and professors and students from Oregon State University's School of Public Affairs. Both groups were kind enough to listen to, and provide feedback on, this research effort.

\section{References}

Amy, D. J. (1987). The Politics of Environmental Mediation. New York, NY: Columbia University Press.

Ash Institute. (2006). Innovations in American Government: Site report, Montana Partners for Fish and Wildife. Cambridge, MA: Harvard University (July).

Backus, P. (2006). Blackfoot conservation effort wins award, $\$ 100,000$ grant. The Missoulian (July 11): A1.

Beierle, T. C., \& Cayford, J. (2002). Democracy in Practice: Public Participation in Environmental Decisions. Washington, D.C.: Resources for the Future Press.

Bingham, L. B., \& O’Leary, R. (2008). Big Ideas in Collaborative Public Management. Armonk, NY: M.E. Sharpe.

Blackfoot Challenge Annual Reports. (2010). Retrieved October 15, 2011, from http://blackfootchallenge.org/Articles/?p=257 
Daniels, S. E., \& Walker, G. B. (2001). Working through environmental conflict: The collaborative learning approach. Westport, CT: Praeger.

Dietz, T., \& Stern, P. C. (2009). Public Participation in Environmental Assessment and Decision Making. Washington DC: National Academies Press.

Fung, A., \& Wright, E. O. (2003). Deepening Democracy: Institutional Innovations in Empowered Participatory Governance. New York: Verso.

Heikkila, T., \& Gerlak, A. K. (2005). The Formation of Large-Scale Collaborative Resource Management Institutions. Policy Studies Journal, 33(4), 583-612. http://dx.doi.org/10.1111/j.1541-0072.2005.00134.x

Kenis, P., \& Raab, J. (2003). What do Policy Networks Do? Paper prepared for the Conference on Democratic Governance. Copenhagen, Denmark.

Khademian, A. M. (2002). Working with Culture: How the Job Gets Done in Public Programs. Washington, DC: CQ Press.

Koontz, T. M., Steelman, T. A., Carmin, J., K. Korfmacher, S., Moseley, C., \& Thomas, C. W. (2004). Collaborative Environmental Management: What Roles for Government? Washington, D.C: Resources for the Future Press.

Layzer, J. (2008). Natural Experiments: Ecosystem Management and the Environment. Cambridge, MA: The MIT Press.

Leach, W., \& Pelkey, N. (2001). Making Watershed Partnerships Work: A Review of the Empirical Literature. Journal of Water Resources Planning and Management, 127(6), 378-385. http://dx.doi.org/10.1061/(ASCE)0733-9496(2001)127:6(378)

Lubell, M. (2000). Attitudinal Support for environmental governance: Do Institutions Matter? Paper presented at the Annual Meeting of the American Political Science Association, Washington, D.C. (August 31 September 3).

Mazmanian, D., \& Kraft, M. (2009). Toward Sustainable Communities. Cambridge, MA: The MIT Press.

Ostrom, E. (1990). Governing the Commons. New York: Cambridge University Press.

Putnam, R. (2000). Bowling Alone: The Collapse and Revival of American Community. New York, NY: Simon and Schuster.

Ragin, C. C. (2008). Redesigning Social Inquiry: Fuzzy Sets and Beyond. Chicago, IL: University of Chicago Press.

Rosa, E. A. (2006). Long-Term Stewardship (LTS) and Risk Management: Analytic and Policy Challenges. In T. L. Leschine (Eds.), Long-Term Management of Contaminated Sites (pp. 227-255). In the Research in Social Problems and Public Policy series, 13. Greenwich, CT: JAI Press. http://dx.doi.org/10.1016/S0196-1152(06)13010-0

Sabatier, P., Focht, W., Lubell, M., Trachtenberg, Z., Vedlitz, A., \& Matlock, M. (2005). Swimming Upstream: Collaborative Approaches to Watershed Management. Cambridge, MA: MIT Press.

Selznick, P. (1957). Leadership in Administration: A Sociological Interpretation. New York, NY: Harper and Row.

Sirianni, C. (2009). Investing in Democracy: Engaging Citizens in Collaborative Governance. Washington, D.C.: The Brookings Institution.

Weber, E. P. (2003). Bringing Society Back In. Cambridge, MA: The MIT Press.

Weber, E. P. (2009). Explaining Institutional Change in Tough Cases of Collaboration: 'Ideas' in the Blackfoot $\begin{array}{lllll}\text { Watershed. Public } & \text { Administration }\end{array}$ http://dx.doi.org/10.1111/j.1540-6210.2008.01976.x

Weber, E. P. (2011). Getting to Resilience in a Climate Protected Community: Early Problem Solving Choices, Ideas, and Governance Philosophy. In Bruce Goldstein (Ed.), Collaborative Resilience: Moving through Crisis to Opportunity. Cambridge, MA: The MIT Press. 


\section{Notes}

Note 1. Notable work on institutional durability has been done by Rosa (2006) in the area of environmental stewardship for the long-term. Another distinguishing characteristic, however, of this work, is that it does not focus specifically on collaboratives, much less the community/watershed-based collaborative examined here.

Note 2. See also Koontz, Steelman, Carmin, Korfmacher, Moseley, and Thomas (2004).

Note 3. See Khademian (2002, 20-21) and Selznick (1957).

Note 4. Traditional USFWS easements in 1995 focused on protecting specific pieces of a landscape, primarily wetlands, grasslands, and the areas immediately surrounding them (buffer zones). The problem here is that natural resource issues such as endangered species and water quality, for example, require a more comprehensive easement approach because they cut across the entire private property, or ranch, landscape. Nor did the traditional approach address development pressures, whether industrial commercial land uses or residential subdivision development, or esthetics. The USFWS now uses the comprehensive easement template in all their regions.

Note 5. This can be interpreted as a sign of success for the BC's managerial strategy of recruiting and involving "focal people" (see Managerial Strategy section below for more).

Note 6 . The value of the continuity of leadership is at least partially confirmed by anecdotal evidence from other watershed collaboratives in the Western U.S. When long-time key leaders left the Henry's Fork Watershed Council, the Applegate Partnership, and the Willapa Alliance, for example, problem-solving performance and programmatic activity suffered significantly (personal interviews 2000 and 2001). 7 "[D] iversity is absolutely critical to this concept" (personal interview 2008). 